\title{
The Factors Affecting the Profitability of Banks: The Case of Latvia
}

\author{
K. Bojāre ${ }^{1}$, I. Romānova ${ }^{2}$
}

\begin{abstract}
:
Bank profitability is a topical issue for a wide range of stakeholders including bank managers and investors, financial supervisors and economic policymakers as well as economists, analysts and journalists.

While the general factors affecting the bank profitability have been thoroughly investigated in the academic literature, differences in the significance of those factors among diverse bank business models and various degrees of banks systemic importance have been analysed less comprehensively. The paper sets out to determine the main factors and their level of impact on profitability of banks in Latvia.
\end{abstract}

The analysis is enhanced by considering three different perspectives of the subdivision of the banking sector in terms of (i) bank business models or (ii) their systemic significance according to the assessment made by both the national supervisory authority and the Single Supervisory Mechanism.

The research is based on the analysis of macroeconomic and bank's financial statement data; the conclusions are drawn based on the analysis of a fixed effects cross-section weights panel model. The research has shown that in Latvia bank profitability is affected mostly by factors such as economic environment, inflation, interest rates (spread), competition in the banking sector as well as individual bank overall effectiveness.

The findings outline the differences between different bank business models and describe the unique banking market in Latvia from the perspective of bank business decisions, at the same time providing valuable insight on profitability aspects that could prove useful, among other parties, to the national supervisory authority and the European Central Bank in bank profitability analysis and assessment of systemically significant institutions.

Keywords: Panel data model, profitability, ROE.

JEL code: G21, C01.

\footnotetext{
${ }^{1}$ University of Latvia, Latvia Kristina.bojare@lu.lv

${ }^{2}$ University of Latvia, Latvia, inna.romanova@lu.lv
} 


\section{Introduction}

The importance of banks in development of national economy is generally recognized. Consequently, bank performance in terms of profitability is important not only for bank management, financial regulators and policy makers, but also for a wide range of stakeholders including investors, economists, analysts etc. The general factors of the bank profitability have been thoroughly investigated in the scientific literature, differences in the significance of those factors among diverse bank business models and various degrees of banks systemic importance have been analysed less comprehensively. The paper aims to determine the main factors and their level of impact on profitability of banks in Latvia.

The research of this topic can be done in many different ways, but as the literature review shows (see Annex 1), the panel data model is the most commonly used tool for determining the factors with measureable significance of impact on specific profitability or other relevant aspects. Taking into account data availability issues in Latvia as well as the responsibility of banks to publicly issue quarterly reports containing specific financial data, profitability can be measured by return on equity (ROE) and return on assets (ROA). Many researchers (Ayanda et al., 2013) have conducted profitability research based on one or both of these profitability measures by describing these factors as proxies demonstrating basic bank management decisions and control (internal factors). Other factors that characterize macroeconomic situation and financial system are out of the control of banks management and therefore are external factors. Other studies (Staikouras and Wood, 2004) also classify factors influencing profitability as internal and external, however given the fact that in this study the authors used publicly available data bank specific factors are limited.

Both, ROE and ROA, are valuable as profitability measurements, but the authors have chosen ROE, as it demonstrates the profitability of the bank from the capital investment side and therefore is more important from the bank shareholders' perspective (Mishkin, 2007). And given the overall target audience for this paper ROE is more appropriate as it provides better insights for bank owners and also because given its mathematical formula it varies at the larger amplitude than ROA and therefore is more sensitive to capture any ongoing changes.

It is a common practice to measure banking profitability using this specific method and variables as proxies for various aspects (see Annex 1), and setting the scope for this research to encompass the banks in Latvia is especially enlightening as it is has not been researched before what the differences regarding the impact of various factors would be keeping in mind dual banking sector specification between banks with residential business model and banks with non-residential business model. Also for regulatory purposes it is valuable to seek out any relevant information regarding profitability as it is the main driving force of any business, banking being no 
exception. Participation of Latvia in the Single Supervisory Mechanism (SSM) adds another specific dimension to this particular research.

\section{The importance of profitability}

As academically acknowledged research reveals there are various factors to consider when analysing possible impact on profitability. Firstly, there are bank specific factors and macroeconomic factors that also include financial sector specific factors. In a prudent manner researchers usually do not choose to include in the model all factors at the same time as many of them tend to indicate the same type of impact. For example, bank size has impact on bank own profitability but that can be analysed using many proxies - asset value, total loan portfolio value etc., basically every bank specific quantitative measure that has been included in the model as an absolute value.

Secondly, there are also considerations regarding specific profitability measures as various researchers have demonstrated the viability of different options - some authors (Hakimi et al., 2015) used Net Interest Margin (NIM) as profitability measure, others (Hanweck and Ryu, 2005) have described connection between the sensitivity of profitability and banks NIM to various financial shocks. Besides, some authors (Jočiene, 2015) measured profitability by using cost to income ratio (CIR), which has been used by many researchers (Lochel and Li, 2011).

While numerous researchers have been analysing bank profitability from different perspectives and using various profitability measures, there are still many aspects that can be further explained. The key aspect for achieving that is sufficiently detailed sample, as for measuring the impact aggregation should be avoided wherever possible as it complicates the necessary quality of impact analysis. Therefore we strived to obtain the fullest publicly available sample of bank specific data for the longest period available.

Legal requirements (Financial and Capital Market Commission (FCMC) Regulation No 46) require banks to publicly disclose annual and quarterly financial data. Public bank profit and loss statements and balance sheets were used to obtain bank-specific data series for this research. Other researchers (Staikouras and Wood, 2004) also tend to rely on this kind of information as it has to be publicly disclosed based on the legislative requirements and is usually consistent with the international accounting standards and therefore comparable internationally.

Topicality of bank profitability, stability and efficiency analysis became especially topical after the global financial crisis (Papagiannis, 2014; Thalassinos et al., 2015). Profitability in economic terms is a positive outcome for every business. The same applies to banks as their overall importance in financial system has been researched and theoretically described through the centuries. Some authors (Solovjova, 2009) describe bank importance as a connected unit in which one individual bank in the 
whole banking system takes part for ensuring higher prosperity level and thus higher economic development. Banking and financial literature in general points out bank significance as intermediaries for channelling financial assets. There are also researchers (Hendricks et al., 2007) who describe banks' importance from the perspective of systemic risk, presenting the conclusion that banks provide fundamental liquidity and maturity transformation that is very important for development of countries economy, at the same time influencing this volatility aspect (systemic risk).

Bank overall importance can be both positive and negative, because it can contribute to many risk factors. They are classified according to their significance in financial market in various ways, e.g., in Europe both as Systemically Important Institutions (SI) in the prudential regime of European Central Bank (ECB) as part of SSM supervision (ECB, 2014), and as Other Systemically Important Institutions (O-SII) according to the provisions of Capital Requirements Directive (CRD); in the case of Latvia this systemic importance assessment is performed by the FCMC according to the transposition of the CRD into national legislation (Credit Institution Law).

Of course, it is not just systemically important banks that are keen for reaching high profitability - it is an aim of all private banks and various stakeholders that have invested in particular bank (or are planning to). Lenders, depositors and bank account holders are also interested for their bank to be profitable as it tends to reflect positively on the stability and sustainability of the bank.

\section{Latvia, Estonia and Lithuania: A comparison}

After outlining the importance of bank profitability, it is necessary to analyse the financial system in which a bank is located. Latvia in many contexts is compared to other Baltic states (Estonia and Lithuania) and while there are many aspects that are common between the countries, there are also some that are different. For example, it is very common to assume that all Baltic banking sectors are dominated by the Scandinavian banks (Jočiene, 2015). But in fact, these banking sectors are substantially heterogeneous (especialy in Latvia).

In terms of banking business models, banking sectors in Estonia and Lithuania are predominantly focused on serving local clients while in Latvia large part of the sector is engaged in servicing foreign clients. As it can be seen in Chart 1 below, banks loan portfolios are the highest in Lithuania and Estonia, but in Latvia only some of the largest banks in terms of asset size have business type that focuses predominantly on residential lending. The local supervisory authorities tend to favour loans to residential clients (loans to non-resident clients, especially if outside the EU, are usually considered highly risky and attract stricter capital and other supervisory requirements). Therefore, measuring loan portfolio as a fraction of total bank assets provides a very indicative breakdown to separate resident and nonresident client oriented bank business models. Public media in Latvia often report 
(Pelane, 2017) that banks engaging in servicing non-residential clients generally are more profitable albeit at the cost of increased risks that, according to FCMC, the local supervisory authority in Latvia, should be limited (FCMC, 2016).

As Chart 1 shows, in Latvia there are multiple large banks (and also many smaller institutions) that only very reluctantly engage in the residential lending activity. It is safe to assume by analysing banks balance sheet data and profit/loss statements, that large part of banks, in order to achieve their comparatively high profit ratios, engage in other, often more lucrative activities such as transaction and investment activities and managing deposits from non-residential clients.

Chart 1. Bank assets and loan-to-assets ratios in Baltic banking sectors, 2016Q4

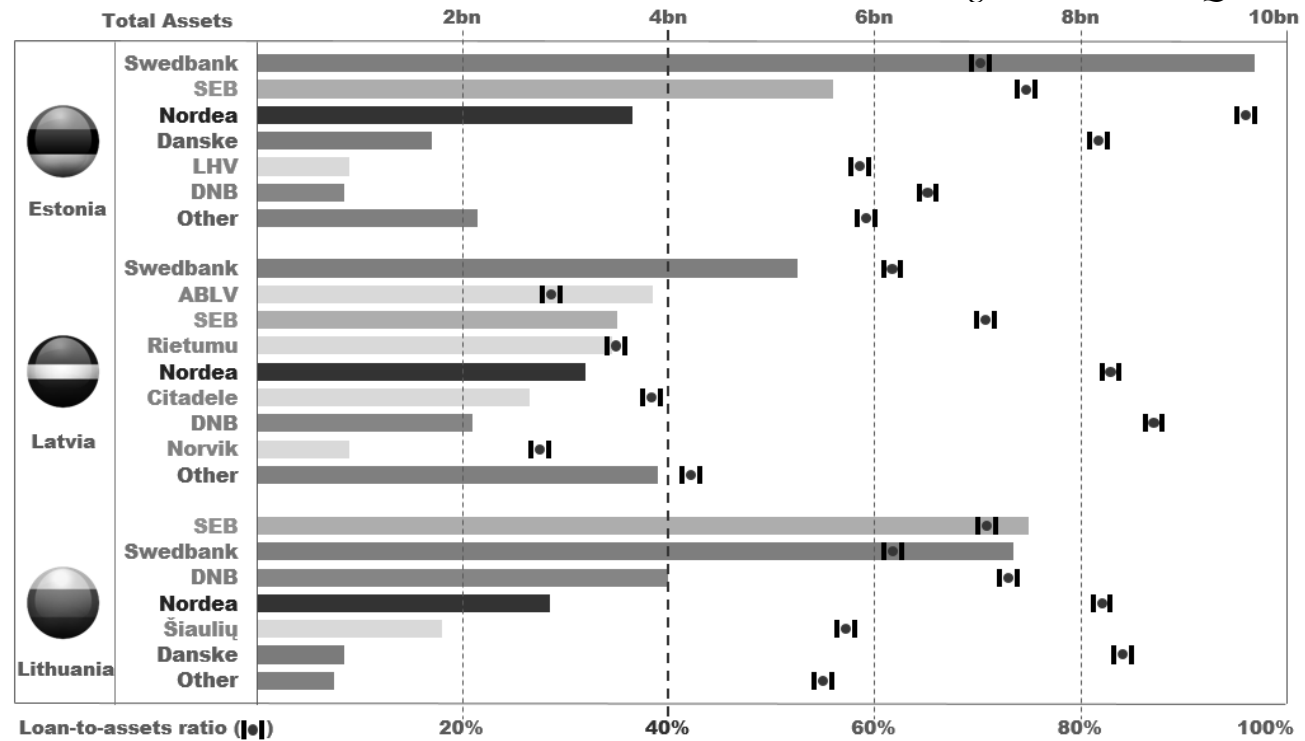

Source: Authors' calculations based on Supervisory agencies' of all Baltic countries and banking associations' in Lithuania and Latvia data, bank press releases.

These differences complicate the comparison between all three Baltic countries. On top of that, in Estonia banking sector consists almost exclusively of the branches or subsidiaries of Nordic banking groups and in Lithuania only 1 bank (Šiauliu Bankas) can seriously compete with Nordic banks. In Latvia Citadele Banka is a strong new player competing with Nordic banks in a local client market while ABLV Bank and Rietumu banka are large institutions that predominantly are engaged in servicing foreign clients.

The Latvian banking sector, differing significantly from Estonian and Lithuanian, is quite unique also when compared to other European countries as it comprises of two sets of banks that have radically different target customer groups and revenue sources. This peculiarity motivated this research on possible differences in the profitability aspects of both type banks. Banks in Estonia and Lithuania were not 
included as those are incomparable when concentrating specifically on two business model types and should be analysed separately.

In order to correctly determine whether a bank belongs to the residential or nonresidential business type banking group, some calculations had to be made. By using bank specific balance sheet data acquired from banks web pages and FCMC appropriate separation could be performed. Chart 2 below shows that by using the data for longer period of time and calculating the average loans-to-asset ratio (not relying exclusively on the most recent data as of 2016Q4) three banks (DNB, Swedbank and SEB) lie in the resident client oriented zone (average loan to asset ratio over $70 \%$ ).

One other bank (Citadele bank) is included in the sample based on the expert judgement - while the historic data (loan to asset ratio in range of 40-55\%) put it closer to the non-resident servicing bank group, the bank's business model during the most of the sample, period has been resident based. Citadele bank is one of the two institutions created in 2010 from a state administered split of failed Parex Bank (which had large non-resident loans and deposits portfolio) - it has since concentrated on the Latvian and the EU market (branch in Estonia, large share of deposit holders from the EU countries), however as it had to maintain significant part of legacy assets and deposits from the Parex Bank, after the split, its loan to assets ratio has been low compared to other banks in the resident clients market as it has been working from scratch to attract local clients from customer bases of its competitors

The sample includes one bank (Trasta Komercbanka) that was liquidated in early 2016 according to information from NCA of Latvia (FCMC, 2016), however as the financial data for this non-residential business type bank was still available in 2015Q4 the bank was included into the overall sample.

\section{Panel data model}

According to the general practice, panel data models are often employed for the measurement of impact from various factors through time (cross-sectional time series). Since every country has its own specific situation, the analysis has to be tailored and based only on bank specific data for obtaining clearer results for this type of research regarding country peculiarities.

According to econometric theory (Harris and Sollis, 2005) application of panel data regression model on acquired data allows to conduct an empirical research on specific factors that changes over time and evaluate the influence of the outcome variable, that in this case is profitability factor ROE. This method allows to analyse heterogenic data sample (that often includes the presence of unit root), it gives variables larger variability that often leads to decreasing of collinearity). Besides, cross section time series guaranties larger number of degree of freedom that at the 
same time provides higher overall effectiveness of the model, allowing analysing of samples with missing data issues (unbalanced models). Moreover, it covers the cases when a model consists of unit root (measured by standard DF test or augmented DF test) as it is proved than when unit number and time period number increases, panel test statistics and overall evaluation tends to converge closer to normally distributive random variables. Of course, there are many shortcomings as well. Nevertheless, for this type of research the benefits exceed the negative aspects in the usage of this model.

Chart 2. Latvian banks loan-to-assets ratio (\%, average over 2005Q4-2016Q4, minimum, maximum and $2016 Q 4$ value)

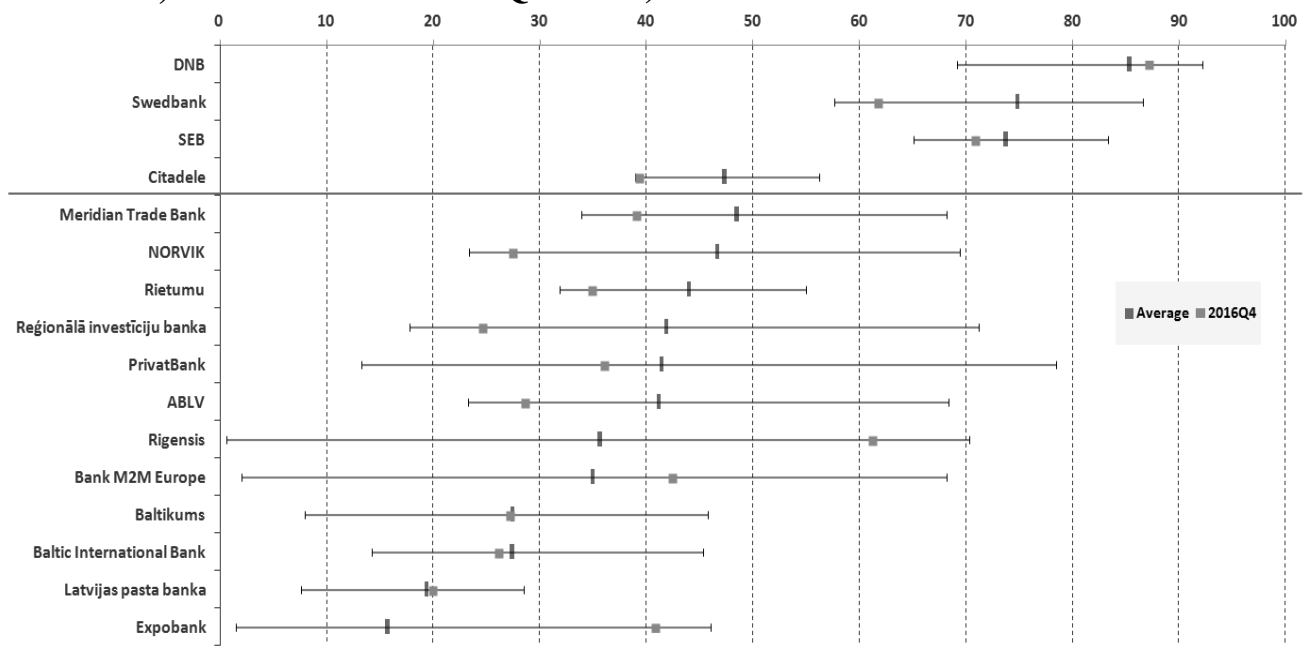

Source: Authors' calculations based on FCMC statistical data and bank published financial data.

The research is based on the fixed effects model as chosen variables $(\mathrm{N})$ included in the model are for the particular purpose (not randomly chosen) and therefore fixed effects model is more suitable model in comparison to a random effects model. Besides, the fixed effects panel data model allows demonstrating how predictor variable and outcome variable correlates through time periods given every specific cross section, in this case - banks (Cross and Validated, 2010).

The Least Squares method (LS) is chosen to evaluate parameters in the regression model, as it is used to determine the coefficients of independent variables in linear regression, which are also at the proper position of the line that has the smallest vertical squared ${ }^{3}$ distance to all data points in the data matrix, giving the best linear equation that describes this model (Hill et al., 2011). The eViews 7.2. programme (the Programme) is used to evaluate and analyse factors influencing profitability.

\footnotetext{
${ }^{3}$ Distance lenght is squared to avoid the possibility for large positive distances to be decreased by large negative distances.
} 
As for the model quality, given the fact that chosen factors are closely linked ${ }^{4}$ the situation is acceptable regarding correlation between those factors (collinearity). Given specifications with this model and type of research that focuses on measuring impact on ROE from various factors, only cross sections were fixed and period fixation had to be excluded for the overall model quality (avoiding dummy variable trap). Still, for missing data issue in the Programme and chosen unbalanced data model with fixed cross section effects as included data are not randomly chosen but with special purposes, for correct unbalanced data weighting the Generalised Least Squares (GLS) cross-section Weights model was used. As a result, it gives the panel model with Estimated Generalised Least Squares (EGLS) with specifications of cross-section weights. This correction allowed to improve the model in light of missing data issues.

The panel data regression is one of the econometric tools that allows to operate with nonstationary data. Regarding the quality of the model, the Programme allows the usage of White cross-section specification with degree of freedom (d.f.) correction as a valuable tool for avoiding heteroscedasticity issue.

Though, from mathematical perspective there are still debates regarding the usage of nonstationary time series for the sake of quality of achieved results and some authors (Phillips and Moon, 2001) have expressed the view that there are still nonunanimous views regarding the nonstationary panel data analysis as well aside from the fact that differentiating time series data or other amendments causes losses of this unique information and possible effects. Especially in this type of research where the scale of impact of factors is the core aim of the research itself.

\section{Data sample and model results}

As previously mentioned the overall data sample consists of 17 banks $^{5}$ (crosssections) and covers the period from 2005Q4 to 2016Q4 that includes 45 periods in total. There were 579 total observations for all bank samples, but smaller for other sub-samples. To achieve the proposed aim of this study, 11 variables were used as proxies to research the impact on profitability (Table1). The proxies were chosen based on theoretical and practical market situation analysis and on previously conducted researches (see Annex 1).

\footnotetext{
${ }^{4}$ One factor consists of the value that is used in another factor numerator and/or denominator.

${ }^{5}$ ABLV Bank, JSC, Baltikums Bank JSC, Joint stock company "Baltic International Bank", "Swedbank" JSC, JSC DNB banka, Bank M2M Europe JSC, JSC "NORVIK BANKA", JSC Expobank, JSC "SEB banka”, JSC "Meridian Trade Bank: , JSC "PrivatBank: , Joint stock company "Regionālā investīciju banka”, Joint stock company "Rietumu Banka”, Joint stock company "Latvijas pasta banka", Joint stock company "Citadele banka”, Rigensis Bank JSC, TRASTA KOMERCBANKA (license annulated in March 3 of 2016).
} 
Table 1. Variables used as proxies in the model

\begin{tabular}{|c|c|}
\hline $\begin{array}{l}\text { Variable in the } \\
\text { model }\end{array}$ & Description \\
\hline GDP & $\begin{array}{l}\text { Gross Domestic Product (GDP). Data acquired from Organization } \\
\text { for Economic co-operation and development (OECD) statistical } \\
\text { data base showing quarterly growth rates of real GDP, change } \\
\text { over previous quarter. } \\
\text { Used as proxy for describing overall macroeconomic situation, } \\
\text { common welfare of the country. }\end{array}$ \\
\hline INTSPREAD & $\begin{array}{l}\text { Interest rate spread value - shows percentage points between long } \\
\text { terms interest rates and short term interest rates. Data acquired } \\
\text { from Eurostat Money market interest rates ( } 1 \text { month rates) were } \\
\text { used for short term interest rates. The Euro convergence criterion } \\
\text { by the means of bond interest rates (with residual maturity of } \\
\text { around } 10 \text { years) used as long period interest rates. This serves as } \\
\text { proxy for measuring the impact from the securities market in } \\
\text { which some banks operate. }\end{array}$ \\
\hline INFLATION & $\begin{array}{l}\text { Inflation was measured as Harmonized Index of Consumer Prices } \\
\text { (HICP). Data acquired from Eurostat These data are serving as } \\
\text { proxy for measuring consumer prices, inflation effects as well as } \\
\text { one of the macroeconomic variables }\end{array}$ \\
\hline HHINDEX & $\begin{array}{l}\text { Herfindhal-Hirschman index (HHI) measures competition in the } \\
\text { market. For dividing market shares the Authors used each banks } \\
\text { asset size. It is very informative proxy that describes financial } \\
\text { sector specific data and displays the effects from other market } \\
\text { participants that can be explained as competitiveness. }\end{array}$ \\
\hline LOG(ASSETS) & $\begin{array}{l}\text { Bank specific data by the means of assets (as logarithmic value } \\
\text { for the quality of model). Data acquired from bank financial } \\
\text { reports and FCMC statistical data reports. Serving as proxy for } \\
\text { bank size, it is widely used in these types of researches as seen in } \\
\text { Annex } 1 \text {. }\end{array}$ \\
\hline LOG(LOANS) & $\begin{array}{l}\text { Bank specific data in terms of loan size (as logarithmic value for } \\
\text { the quality of model). Data acquired from banks financial reports } \\
\text { and FCMC statistical data reports. Giving the fact that only } 4 \\
\text { banks are included as residential business type banks, then it } \\
\text { mostly describes influence from banks' lending activities. }\end{array}$ \\
\hline $\begin{array}{c}\text { LOG(INT_INCO } \\
\text { ME) }\end{array}$ & $\begin{array}{l}\text { Bank specific data in terms of interest income (as logarithmic } \\
\text { value for the quality of model). Data acquired from bank financial } \\
\text { reports and FCMC statistical data reports. It basically describes } \\
\text { banks' profitability influence from banks management - effective } \\
\text { acquisition of interests. }\end{array}$ \\
\hline $\begin{array}{c}\text { LOG(INT_EXPE } \\
\text { ND) }\end{array}$ & $\begin{array}{l}\text { Bank specific data in terms of interest expenses (as logarithmic } \\
\text { value for the quality of model). Data acquired from bank financial } \\
\text { reports and FCMC statistical data reports. The same as for interest } \\
\text { income proxy, also this shows banks managements' effectiveness. }\end{array}$ \\
\hline $\begin{array}{c}\text { INT_EXP_TO_IN } \\
\text { T_INC }\end{array}$ & $\begin{array}{l}\text { Bank specific data in terms of interest expenses ratio to interest } \\
\text { income. Ratios calculated based on bank financial reports and } \\
\text { FCMC statistical data reports. Showing basing effectiveness from }\end{array}$ \\
\hline
\end{tabular}




\begin{tabular}{|c|c|}
\hline & $\begin{array}{l}\text { banks interests to manage them correctly - ensuring that expenses } \\
\text { are less than income. This is more informative proxy than just } \\
\text { plain logarithmic interest income or interest expenses values. For } \\
\text { detailed information previously shown two proxies were used } \\
\text { (interest income and interest expenses). }\end{array}$ \\
\hline $\begin{array}{c}\text { LOANS_TO_ASS } \\
\text { ETS }\end{array}$ & $\begin{array}{l}\text { Bank specific data showing ratio between loans and assets. Data } \\
\text { acquired from bank financial reports and FCMC statistical data } \\
\text { reports. It serves as proxy showing impact on profitability from } \\
\text { banks business decisions - either increasing or decreasing loan } \\
\text { portfolio in the assets. Basically shows impact on profitability } \\
\text { from lending activities. }\end{array}$ \\
\hline $\begin{array}{c}\text { INT_INC_TO_LO } \\
\text { ANS }\end{array}$ & $\begin{array}{l}\text { Bank specific data showing ratio between interest income and } \\
\text { loans. Data acquired from bank financial reports and FCMC } \\
\text { statistical data reports. It is proxy that displays efficiency from } \\
\text { issued loans and this is more important for residential business } \\
\text { type banks as their main source of income is lending. }\end{array}$ \\
\hline
\end{tabular}

Source: Based on theoretical review of different studies, see Annex 1.

Analysis of collected data shows that the set of proxies regarding bank specific data is limited as well as the missing data issue is topical, putting constraints on bank specific research regarding bank profitability.

The evaluation of impact on bank profitability analysis is made based on seven section data samples (Table 2) as there are differences regarding not only business models, but also proportionality divisions (O-SII) and ECB supervisory divisions. As for the explanatory power of the model for each of these sub-samples, as can be seen in Table 2, coefficient of determination ( $R$ squared) lingers around $0.6-0.8$ in all cases which can be considered good for this type of model given the sample and data availability issues.

Table 2. Impact on profitability in various banking sections

\begin{tabular}{|c|c|c|c|c|c|c|c|}
\hline & All banks & $\begin{array}{c}\text { Banks } \\
\text { with } \\
\text { residential } \\
\text { business } \\
\text { model }\end{array}$ & $\begin{array}{c}\text { Banks } \\
\text { with non- } \\
\text { residentia } \\
1 \\
\text { business } \\
\text { model } \\
\end{array}$ & $\mathrm{O}$ - SII & $\begin{array}{c}\text { Non O- } \\
\text { SII }\end{array}$ & $\begin{array}{c}\text { ECB } \\
\text { SI }\end{array}$ & $\begin{array}{c}\text { ECB } \\
\text { LSI } \\
\end{array}$ \\
\hline \multirow{3}{*}{ GDP } & & & & $\begin{array}{c}1.635 * * \\
*\end{array}$ & & $\begin{array}{c}1.98 * * \\
*\end{array}$ & \\
\hline & $\begin{array}{c}0.795 * * * \\
(4.356)\end{array}$ & $\begin{array}{c}1.973 * * * \\
(5.969)\end{array}$ & $\begin{array}{c}0.508 * * * \\
(2.678)\end{array}$ & $\begin{array}{c}* \\
(7.842)\end{array}$ & $\begin{array}{c}0.468 * * * \\
(2.463)\end{array}$ & $\begin{array}{c}* \\
(6.733)\end{array}$ & $\begin{array}{c}0.275 \\
(1.457) \\
-\end{array}$ \\
\hline & & & - & & - & & $1.183 * *$ \\
\hline \multirow[t]{2}{*}{ INTSPREAD } & $-1.23 * * *$ & -1.194 & $1.197 * * *$ & -0.781 & $1.175^{* * * *}$ & -0.912 & $*$ \\
\hline & $(-3.918)$ & $(-1.618)$ & $(-4.465)$ & $(-1.443)$ & $(-4.086)$ & $(-1.25)$ & $(-4.46)$ \\
\hline \multirow{2}{*}{ INFLATION } & $6.334 * * *$ & $10.97 * * *$ & $5.205 * * *$ & $\begin{array}{l}7.378 * * \\
*\end{array}$ & $4.729 * * *$ & & $6.01 * * *$ \\
\hline & (3.726) & (3.421) & $(3.226)$ & (2.986) & (2.922) & (2.397) & (3.711) \\
\hline \multirow[t]{2}{*}{ HHINDEX } & $0.007 *$ & 0.003 & $0.009 * *$ & 0.004 & $0.014 * * *$ & -0.002 & 0.005 \\
\hline & (1.783) & (0.37) & (2.381) & (0.657) & (3.411) & $0.149)$ & (1.341) \\
\hline LOG(ASSETS) & 1.004 & 26.451 & 2.181 & $60.79 * *$ & $5.134 * * *$ & 39.876 & 2.616 \\
\hline
\end{tabular}




\begin{tabular}{|c|c|c|c|c|c|c|c|}
\hline \multirow{3}{*}{ LOG(LOANS) } & $(0.358)$ & $(0.595)$ & $(0.917)$ & $(4.438)$ & $(2.483)$ & (1.433) & $(1.082)$ \\
\hline & 2.171 & -23.6 & 1.141 & $\begin{array}{l}55.156^{*} \\
* *\end{array}$ & -1.016 & 28.206 & -0.317 \\
\hline & $(0.907)$ & $(-0.484)$ & $(0.623)$ & $(-3.606)$ & $(-0.621)$ & $0.896)$ & $(-0.164)$ \\
\hline \multirow[t]{2}{*}{ LOG(INT_INCOME) } & -0.635 & -12.668 & 1.81 & $10.469^{*}$ & 0.858 & -6.97 & 1.329 \\
\hline & $(-0.273)$ & $(-1.636)$ & $(1.06)$ & $(-1.742)$ & $(0.531)$ & $0.778)$ & $(0.615)$ \\
\hline \multirow[t]{2}{*}{ LOG(INT_EXPEND) } & $3.197^{*}$ & $9.872 * * *$ & 1.019 & $8.064 * *$ & $2.077^{*}$ & 3.296 & 1.888 \\
\hline & $(1.706)$ & $(2.576)$ & $\begin{array}{c}(0.780) \\
-\end{array}$ & $\begin{array}{c}(2.204) \\
-\end{array}$ & $\begin{array}{c}(1.685) \\
-\end{array}$ & $(0.672)$ & $\begin{array}{c}(1.09) \\
-\end{array}$ \\
\hline \multirow{3}{*}{$\begin{array}{l}\text { INT_EXP_TO_INT_I } \\
\text { NC }\end{array}$} & & - & $25.616^{* * *}$ & $74.834 *$ & $22.235 * *$ & - & $31.73^{* * *}$ \\
\hline & & $76.093 * * *$ & & & & $\begin{array}{c}34.359 \\
(-\end{array}$ & \\
\hline & $(-5.239)$ & $(-5.28)$ & $(-5.68)$ & $\begin{array}{l}(-7.563) \\
1.409 * *\end{array}$ & $(-4.856)$ & 1.152) & $(-4.221)$ \\
\hline \multirow{3}{*}{$\begin{array}{l}\text { LOANS_TO_ASSETS } \\
\text { INT_INC_TO_LOAN } \\
\mathrm{S}\end{array}$} & -0.078 & 0.784 & -0.07 & $*$ & 0.041 & 0.883 & 0.009 \\
\hline & $(-0.91)$ & $(1.001)$ & $(-1.01)$ & (3.947) & $(0.587)$ & $(1.32)$ & $(0.12)$ \\
\hline & $\begin{array}{r}0.036 \\
(0.835) \\
\end{array}$ & $\begin{array}{r}2.032 \\
(1.334) \\
\end{array}$ & $\begin{array}{c}0.016 \\
(0.454)\end{array}$ & $\begin{array}{l}1.483 \\
(1.415)\end{array}$ & $\begin{array}{c}-0.016 \\
(-0.529)\end{array}$ & $\begin{array}{l}1.872 \\
(1.126)\end{array}$ & $\begin{array}{c}0.016 \\
(0.425)\end{array}$ \\
\hline Periods included & 45 & 45 & 45 & 45 & 45 & 45 & 45 \\
\hline $\begin{array}{l}\text { Cross-sections } \\
\text { included }\end{array}$ & 17 & 4 & 13 & 6 & 11 & 3 & 14 \\
\hline $\begin{array}{ll}\text { Total } & \text { panel } \\
\text { observations } & \end{array}$ & 579 & 147 & 432 & 225 & 354 & 127 & 452 \\
\hline $\mathrm{R}^{2}$ & 0.608 & 0.816 & 0.616 & 0.833 & 0.585 & 0.833 & 0.6 \\
\hline
\end{tabular}

Source: Author's own assumptions based on theoretical review of the subject and different studies in Annex 1.

Notes: numbers show as follows - coefficient value, significance level (significance at the $1 \% * * *$, at the $5 \% * *$, and at the $10 \% *$ ), and $t$-statistic value.

\section{Research results and discussion}

The application of the panel regression on bank specific data allowed to conduct an empirical research with higher quality results comparing to the use of aggregated bank data. The research findings outline the differences between bank business models Based on research, we conclude:

1. Factors influencing the profitability of separate sub-groups of Latvian banking sector - both based on the resident/non-resident targeted business model and based on the systemic importance of the banks differ significantly.

2. Nevertheless, profits of all banks in the sample, regardless of their belonging to specific sub-group, are in general affected most profoundly by macroeconomic factors such as GDP growth and inflation level, as well as bank individual effectiveness characterized by their management of interest income and expenses. 
3. Profits of banks with business model based on servicing resident clientele are affected differently compared to banks with nonresidential business type model as their main sources of income are in large part unrelated the first group strive to secure their profits by issuing loans while the second engages heavily in investment activities and client account management.

4. As there are more players in the non-resident servicing business model group of banks, their profitability is significantly affected also from the competitiveness aspect. Importance of this factor may lead to questioning on whether 16 active banks in a small open economy such as Latvia are not too many to ensure adequate return on capital in longer term Lithuania and Estonia have less market participants, however it must be kept in mind that banks there do not engage in servicing non-resident customers. Globalization tendencies and information technology advances lead to many changes that are particularly hard for smaller banks to adjust and comply with. Regulatory burden from both the local supervisory authorities and ECB as part of SSM should also be considered as it is heavier for non-resident business type banks in line with the higher risks they engage in.

5. Unsurprisingly, non-resident business type banks and non-O-SII banks (that are all non-resident business type banks) display similarities regarding impact of various factors on their profitability - that includes high impact of interest rates (spread).

6. Both O-SII and non-O-SII banks exhibit high impact on profitability from various aspects that include bank size and effective interest expense management. Based on the indicators employed in the process of O-SII identification, the observed impact of factors such as banks size, management and business activities on their profits is in line with expectations.

7. As for ECB SI and ECB less significant institutions (LSI), dividing banks in these groups entirely by their asset size, (ECB approach) is not very informative factor about the impact on profitability as this division does not provide clear-cut and significant conclusions.

The research results can be used by bank stakeholders for careful assessment of business planning, investment activities banks, and common welfare of the institutions taking into account their special characteristics. Besides, impact of different factors on banks profitability is very important in terms of bank regulation and monetary policy to balance profitable banking sector and prudent management of banks and overall economics.

\section{Conclusions}

The Latvian banking sector, with its sharp division in two different sets of banks servicing separate customer groups and chasing distinct revenue streams, proves to 
be substantially different from other Baltic banking sectors thereby justifying the exclusive focus on it in this research. In Estonia and Lithuania banking sectors mainly consist of branches and subsidiaries of Nordic institutions that concentrate on servicing the local clientele - according to the assessment made in this study, there are four similar banks also in Latvia that in the future could be included in the Estonian and Lithuanian banking sample to analyze the profitability of banks servicing local customers in Baltic States.

The separation of the Latvian banking sector into two groups was based on the method introduced specifically to account for the peculiarities of the Latvian banking system. The research has shown that in Latvia bank profitability is affected mostly by such factors as economic environment, inflation, interest rates (spread), competition in the banking sector as well as individual bank overall effectiveness. The findings show the differences between different bank business models providing valuable insight on profitability aspects that could prove useful for different bank stakeholders.

\section{References:}

Akbas, H.E. 2012. Determinants of Bank Profitability: an Investigation on Turkish Banking Sector. Yildiz Technical University, 8-9.

Albulescu, C.T. 2015. Banks' Profitability and Financial Soundness Indicators: A Macrolevel Investigation in Emerging Countries. 2nd Global Conference on Business, Economics, Management and Tourism. Procedia Economics and Finance, 23, 203209.

Association of Lithuanian Banks, 2017. Main indicators of Banks. Vilnius. http://www.lba.lt/en/main-indicators-of-banks

Ayanda, A.M., Christopher, I., Mudashiru, M.A. 2013. Determinants of Banks' Profitability in a Developing Economy: evidence from Nigerian Banking Industry. Interdisciplinary Journal of Contemporary Research in Business, 4(9), 155-181.

Boitan I. A., 2015. Determinants of Sustainable Banks' Profitability. Evidence from EU Countries. Financial Studies, 19(1), 21-39.

Chronopoulos, D.K., Liu, H., McMillan, F.J., Wilson, J.O.S. 2013. The Dynamics of US Bank Profitability. Working Papers in responsible banking \& finance: Center for Responsible Banking \& Finance. University of St. Andrews, School of Management.

Cross, V. 2010. What is the Difference Between Fixed Effect, Random Effect and Mixed Effect Models, https://stats.stackexchange.com/questions/4700/what-is-thedifference-between-fixed-effect-random-effect-and-mixed-effect-mode.

ECB, 2014. Guide to Banking Supervision, Frankfurt am Main, Germany: ECB, https://www.ecb.europa.eu/pub/pdf/other/ssmguidebankingsupervision201409en.pdf

Eurostat, 2017. Various sources, http://ec.europa.eu/eurostat/data/database

FCMC Regulations No 46. 2006. Regulations on the Preparation of Annual Accounts and Annual Consolidated Accounts for Banks, Investment Brokerage Firms and Investment Management Companies, http://www.fktk.lv/en/law/creditinstitutions/fcmc-regulations.html? start $=20$

FCMC, 2017. Various sources. www.fktk.lv 
Hakimi, A., Hamdi, H., Djelassi, M. 2015. Testing the Concentration-Performance Relationship in the Tunisian Banking Sector. East-West Journal of Economics and Business, 18(2), $22 \mathrm{p}$.

Hanweck, G., Ryu, L. 2005. The Sensitivity of Bank Net Interest Margins and Profitability to Credit, Interest-Rate, and Term-Structure Shocks Across Bank Product Specializations. Working Paper, 02. pp. 77.

Harris, R., Sollis, R., 2003. Applied Time Series Modelling and Forecasting. John Wiley \& Sons Ltd, England, 189-192.

Hendricks, D., Kambhu, J., Mosser, P. 2007. Systemic Risk and the Financial System. The Federal Reserve Bank of New York, 16.

Hill, R.C., Griffiths, W.E., Lim, G.C. 2011. Principles of Econometrics, Fourth Edition. John Wiley \& Sons, Inc. United States of America, 51.

Jočiene, A. 2015. Intellectual Economics, 9(1). Scandinavian Bank Subsidiaries in the Baltics: Have They All Behaved in a Similar Way. Vilnius University, Vilnius, Lithuania, 43-54.

Jočiene, A. 2015. Occasional Paper Series No 5/2015. Business Models of Scandinavian Banks Subsidiaries in the Baltics: Identification and analysis. Bank of Lithuania, Vilnius, 71.

Lietuvos Bankas, 2017. Main Indicators of Banking Sector Activities. Vilnius, https://www.lb.lt/uploads/documents/files/banku_sektoriaus_rodikliai_2017-0101_solo_eur_eng.pdf.

Lochel, H., Li, H.X. 2011. Understanding the High Profitability of Chinese Banks. Frankfurt School - Working Paper Series, 177, 35.

Mishkin, F.S. 2007. The Economics of Money, Banking, and Financial Markets (eight edition). The Addison-Wesley series in economics, 232.

Mokni, R.B.S., Rachdi, H. 2014. Assessing the bank profitability in the MENA region: A comperative Analysis Between Conventional and Islamic Bank. Internal Journal of Islamic and Middle Eastern Finance and Management, 7(3), 305-332.

OECD, 2017. Quarterly National Accounts, https://stats.oecd.org/index.aspx?queryid=350

Papagiannis, G.P. 2014. Measurement of Efficiency in Greek Banking Industries in the Light of the Financial Crisis. European Research Studies Journal, 17(1), 19-38.

Petria, N., Capraru, B., Ihnatov, I., 2015. Determinants of Banks' Profitability: Evidence From EU 27 Banking Systems. 7th International Conference on Globalization and Higher Education in Economics and Business Administration, GEBA 2013. Procedia Economics and Finance, 20, 518-524.

Phillips, P.C.B., Moon, H.R. 2001. Nonstationary Panel Data analysis: An Overview of Some Recent Developments. Cowles Foundation for research in Economics, Yale University, 25.

Solovjova, I. 2009. Stability Problems of Banking System. Riga, 24.

Staikouras, C.K., Wood, G.E. 2004. The Determinants of European Bank Profitability. International Business \& Economics Research Journal, 3(6), 57-68.

Tan, Y., Floros, C. 2012. Bank Profitability and Inflation: The Case of China. Journal of Economic Studies, 36(6), 675-696.

Thalassinos, I.E., Pintea M., Iulia, R.P. 2015. The Recent Financial Crisis and Its Impact on the Performance Indicators of Selected Countries during the Crisis Period : A Reply. International Journal in Economics and Business Administration, 3(1), 3-20. 
Annex 1. The links of bank profitability factors with macroeconomic indicators in selected studies*

\begin{tabular}{|c|c|c|c|c|c|c|c|c|c|c|c|c|c|}
\hline & \multicolumn{2}{|c|}{$\begin{array}{c}\text { PetriaN., } \\
\text { Capraru B., } \\
\text { Ihnatov I., } \\
(2015)\end{array}$} & \multicolumn{2}{|c|}{$\begin{array}{c}\text { Akbas } \\
\text { H.E., } \\
\text { (2012) }\end{array}$} & \multicolumn{2}{|c|}{$\begin{array}{c}\text { Tan Y., } \\
\text { Floros } \\
\text { C., } \\
(2012)\end{array}$} & \multicolumn{2}{|c|}{$\begin{array}{c}\text { Mokni } \\
\text { R.B.S., } \\
\text { Rachdi } \\
\text { H., } \\
(2014)\end{array}$} & $\begin{array}{c}\text { Chro } \\
\text { nopo } \\
\text { ulos } \\
\text { D.K., } \\
\text { Liu } \\
\text { H., } \\
\text { Fiona } \\
\text { J. } \\
\text { McM } \\
\text { illan } \\
\text { F.J., } \\
\text { Wils } \\
\text { on } \\
\text { J.O.S } \\
\text {., } \\
(2013 \\
\text { ) }\end{array}$ & \multicolumn{2}{|c|}{$\begin{array}{l}\text { Boitan I.A., } \\
\text { (2015) }\end{array}$} & \multicolumn{2}{|c|}{$\begin{array}{c}\text { Albules } \\
\text { cu } \\
\text { C.T., } \\
(2015)\end{array}$} \\
\hline & $\underset{\mathbf{E}}{\mathrm{ROA}}$ & $\begin{array}{c}\mathrm{ROA} \\
\mathrm{A}\end{array}$ & $\begin{array}{l}\mathbf{R} \\
\mathbf{O} \\
\mathrm{A}\end{array}$ & $\begin{array}{l}\mathbf{R} \\
\mathbf{O} \\
\mathbf{E} \\
\end{array}$ & $\begin{array}{l}\mathrm{R} \\
\mathbf{O} \\
\mathrm{A}\end{array}$ & $\begin{array}{l}\text { NI } \\
\text { M }\end{array}$ & $\begin{array}{l}\mathbf{R} \\
\mathbf{O} \\
\mathbf{A} \\
\end{array}$ & $\begin{array}{l}\mathbf{R} \\
\mathbf{O} \\
\mathbf{E} \\
\end{array}$ & ROA & $\underset{\text { I }}{\text { ROA }}$ & $\begin{array}{c}\text { ROA } \\
\text { II }\end{array}$ & $\begin{array}{l}\mathbf{R} \\
\mathbf{O} \\
\mathrm{A} \\
\end{array}$ & $\begin{array}{l}\mathbf{R} \\
\mathbf{O} \\
\mathbf{E} \\
\end{array}$ \\
\hline 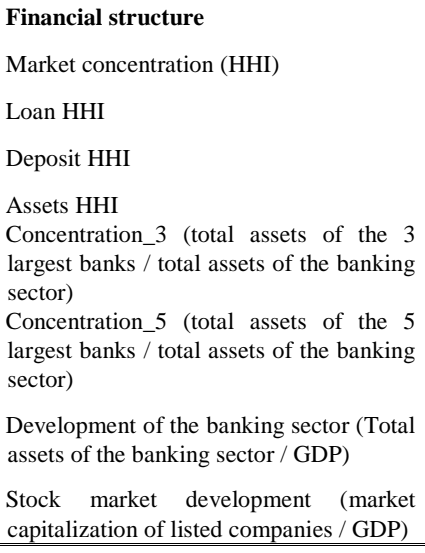 & & ++ & & + & & & & & $\begin{array}{l}+++ \\
+++\end{array}$ & & & & \\
\hline $\begin{array}{l}\text { Macroeconomic indicators } \\
\text { Inflation (inflation, GDP deflator (annual, } \\
\% \text { ) } \\
\text { Economic growth (GDP per capita } \\
(\text { annual, \%)) } \\
\text { Log GDP } \\
\text { Harmonized consumer price index } \\
\text { (HCPI) } \\
\text { Consumer price index (annual, \%) } \\
\text { GDP growth } \\
\text { Effective tax rate (bank tax payments / } \\
\text { EBT) }\end{array}$ & $\begin{array}{l}0 \\
+++\end{array}$ & $\begin{array}{l}0 \\
+++\end{array}$ & + & 0 & & & & 0 & +++ & $\begin{array}{l}+++ \\
0\end{array}$ & $\begin{array}{l}+++ \\
0\end{array}$ & & \\
\hline
\end{tabular}

$*+,++,++$ shows the significance level, respectively at the $10 \%, 5 \%$ and $1 \%$.

ROAE - average return on equity, ROAA - average return on assets, ROA - return on assets, ROE - return on equity, NIM - net interest income to earning assets ratio, ROA I - for calculations used Pooled Least Squares method, ROA II - for calculations used GLS Cross Section Weights method. 


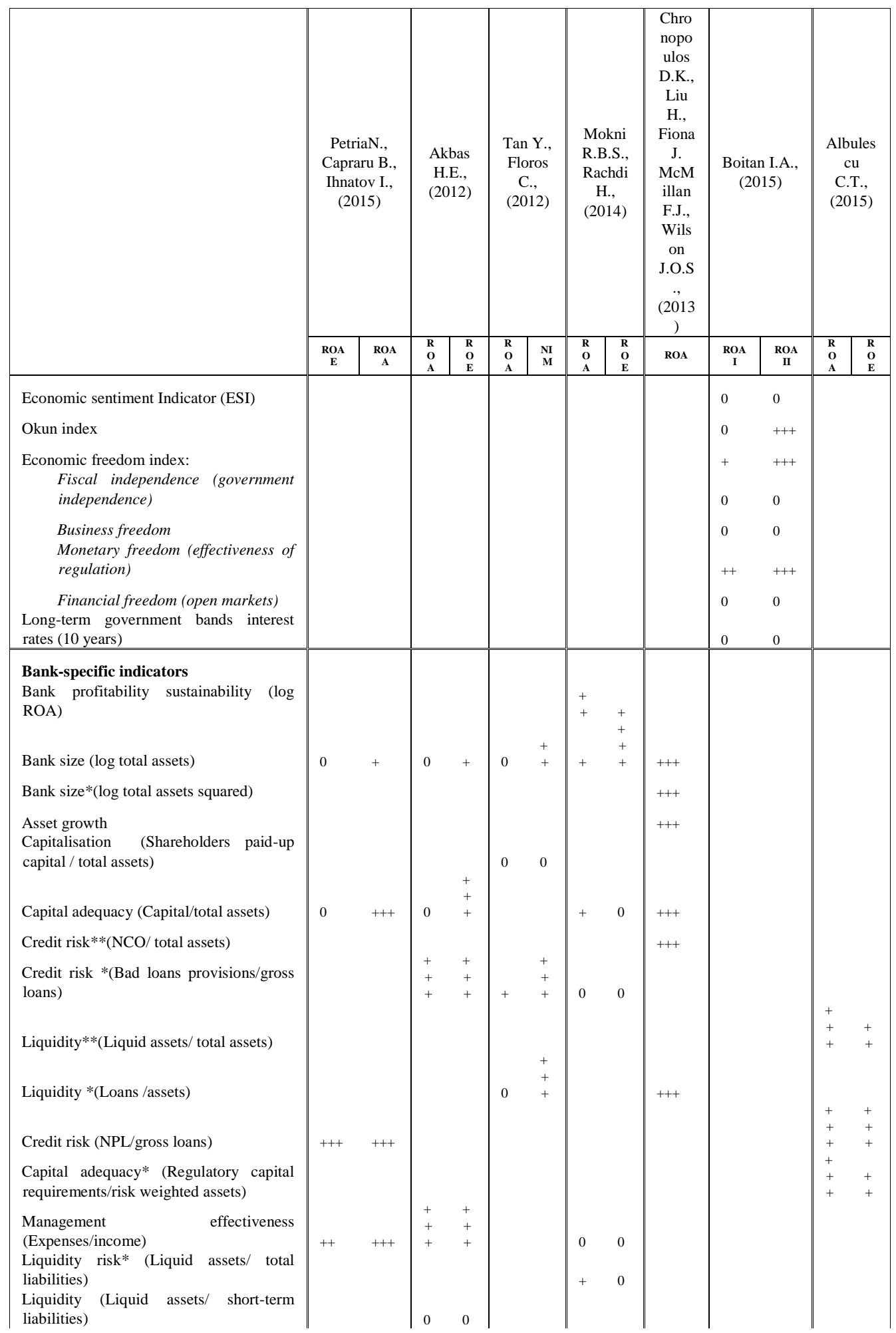




\begin{tabular}{|c|c|c|c|c|c|c|c|c|}
\hline & $\begin{array}{c}\text { PetriaN., } \\
\text { Capraru B., } \\
\text { Ihnatov I., } \\
(2015)\end{array}$ & $\begin{array}{l}\text { Akbas } \\
\text { H.E., } \\
\text { (2012) }\end{array}$ & $\begin{array}{c}\text { Tan Y., } \\
\text { Floros } \\
\text { C., } \\
(2012)\end{array}$ & $\begin{array}{l}\text { Mokni } \\
\text { R.B.S., } \\
\text { Rachdi } \\
\text { H., } \\
(2014)\end{array}$ & $\begin{array}{c}\text { Chro } \\
\text { nopo } \\
\text { ulos } \\
\text { D.K., } \\
\text { Liu } \\
\text { H., } \\
\text { Fiona } \\
\text { J. } \\
\text { McM } \\
\text { illan } \\
\text { F.J., } \\
\text { Wils } \\
\text { on } \\
\text { J.O.S } \\
\text {., } \\
\text { (2013 } \\
\text { ) }\end{array}$ & \multicolumn{2}{|c|}{$\begin{array}{c}\text { Boitan I.A., } \\
\text { (2015) }\end{array}$} & $\begin{array}{c}\text { Albules } \\
\text { cu } \\
\text { C.T., } \\
(2015)\end{array}$ \\
\hline & $\underset{\mathbf{E}}{\mathbf{R O A}}$ & \begin{tabular}{l|l}
$\mathbf{R}$ & $\mathbf{R}$ \\
$\mathbf{O}$ & $\mathbf{O}$ \\
$\mathbf{A}$ & $\mathbf{E}$
\end{tabular} & \begin{tabular}{l|l}
$\mathbf{R}$ & NI \\
$\mathbf{O}$ & $\mathbf{M}$ \\
$\mathbf{A}$ & $\mathbf{M}$ \\
\end{tabular} & \begin{tabular}{l|l}
$\mathbf{R}$ & $\mathbf{R}$ \\
$\mathbf{O}$ & $\mathbf{O}$ \\
$\mathbf{A}$ & $\mathbf{E}$
\end{tabular} & ROA & $\underset{\text { I }}{\text { ROA }}$ & $\stackrel{\text { ROA }}{\text { II }}$ & $\begin{array}{l}\mathbf{R} \\
\mathbf{O} \\
\mathbf{A}\end{array}$ \\
\hline $\begin{array}{l}\text { Liquidity risk (Loans / client deposits) } \\
\text { Business indicator (Other operational } \\
\text { income/ average assets) } \\
\text { Tax indicator (tax expenses/ earnings } \\
\text { before taxes) } \\
\text { Cost-effectiveness (other expenses / total } \\
\text { assets) } \\
\text { Income diversification (non- interest } \\
\text { income / total (operating) income) } \\
\text { Net interest income (interest margin } \\
\text { income /gross income) } \\
\text { Administrative expenditure (Non-interest } \\
\text { expenses / gross income) } \\
\text { Non-traditional activity (Non-interest } \\
\text { income / gross income)) } \\
\text { Labour productivity (gross income / } \\
\text { number of employees) } \\
\text { Interest rate risk ((Interest rate sensitive } \\
\text { assets - Interest rate sensitive } \\
\text { liabilities)/total capital) } \\
\text { Off-balance sheet activities (Non-interest } \\
\text { income/ total assets) } \\
\text { Off-balance sheet activities*(Derivatives/ } \\
\text { total assets) } \\
\text { Bank ownership } \\
\text { Merger and Acquisition } \\
\text { Listed banks } \\
\text { Bank age }\end{array}$ & $\begin{array}{l}+++ \\
+++ \\
+++\end{array}$ & & $\begin{array}{ll}+ & + \\
+ & + \\
+ & + \\
+ & + \\
+ & + \\
+ & +\end{array}$ & $\begin{array}{ll}+ & \\
+ & \\
+ & + \\
+ & + \\
0 & 0 \\
0 & 0 \\
0 & 0 \\
0 & + \\
0 & 0\end{array}$ & +++ & & & $\begin{array}{ll}+ & + \\
+ & + \\
+ & + \\
+ & + \\
+ & +\end{array}$ \\
\hline Cross-section & $\begin{array}{c}1098 \\
\text { individual } \\
\text { bank data by } \\
\text { country }\end{array}$ & $\begin{array}{c}26 \text { bank } \\
\text { individu } \\
\text { al data }\end{array}$ & $\begin{array}{l}101 \text { bank } \\
\text { individu } \\
\text { al data }\end{array}$ & $\begin{array}{c}15 \\
\text { conventi } \\
\text { onal and } \\
15 \\
\text { Islamic } \\
\text { banks } \\
\text { individu } \\
\text { al data } \\
\text { by } \\
\text { country }\end{array}$ & $\begin{array}{c}\text { Indivi } \\
\text { dual } \\
\text { data of } \\
17500 \\
\text { big } \\
\text { comm } \\
\text { ercial } \\
\text { banks } \\
\text { (assets } \\
>100 \\
000 \\
\text { USD) }\end{array}$ & & & $\begin{array}{c}\text { Bank } \\
\text { sector } \\
\text { consolid } \\
\text { ated data } \\
\text { by } \\
\text { country }\end{array}$ \\
\hline Countries included & EU-27 & Turkey & China & $\begin{array}{l}\text { MENA } \\
\text { (Middle } \\
\text { East un } \\
\text { North } \\
\text { Africa) }\end{array}$ & USA & & & $\begin{array}{c}\text { Developi } \\
\text { ng } \\
\text { countries } \\
\text { (Chile, } \\
\text { Colombi }\end{array}$ \\
\hline
\end{tabular}




\begin{tabular}{|c|c|c|c|c|c|c|c|c|c|c|c|c|c|}
\hline & \multicolumn{2}{|c|}{$\begin{array}{l}\text { PetriaN., } \\
\text { Capraru B., } \\
\text { Ihnatov I., } \\
(2015)\end{array}$} & \multicolumn{2}{|c|}{$\begin{array}{c}\text { Akbas } \\
\text { H.E., } \\
(2012)\end{array}$} & \multicolumn{2}{|c|}{$\begin{array}{c}\text { Tan Y., } \\
\text { Floros } \\
\text { C., } \\
(2012)\end{array}$} & \multicolumn{2}{|c|}{$\begin{array}{l}\text { Mokni } \\
\text { R.B.S., } \\
\text { Rachdi } \\
\text { H., } \\
\text { (2014) }\end{array}$} & $\begin{array}{c}\text { Chro } \\
\text { nopo } \\
\text { ulos } \\
\text { D.K., } \\
\text { Liu } \\
\text { H., } \\
\text { Fiona } \\
\text { J. } \\
\text { McM } \\
\text { illan } \\
\text { F.J., } \\
\text { Wils } \\
\text { on } \\
\text { J.O.S } \\
\text {, } \\
(2013 \\
\text { ) }\end{array}$ & \multicolumn{2}{|c|}{$\begin{array}{c}\text { Boitan I.A., } \\
\text { (2015) }\end{array}$} & \multicolumn{2}{|c|}{$\begin{array}{c}\text { Albules } \\
\text { cu } \\
\text { C.T., } \\
(2015)\end{array}$} \\
\hline & $\underset{\mathbf{E}}{\mathrm{ROA}}$ & $\underset{\mathbf{A}}{\mathrm{ROA}}$ & $\begin{array}{l}\mathbf{R} \\
\mathbf{O} \\
\mathrm{A} \\
\end{array}$ & $\begin{array}{l}\mathbf{R} \\
\mathbf{O} \\
\mathbf{E} \\
\end{array}$ & $\begin{array}{l}\mathbf{R} \\
\mathbf{O} \\
\mathrm{A} \\
\end{array}$ & $\begin{array}{l}\text { NI } \\
\text { M }\end{array}$ & $\begin{array}{l}\mathbf{R} \\
\mathbf{O} \\
\mathrm{A} \\
\end{array}$ & $\begin{array}{l}\mathbf{R} \\
\mathbf{O} \\
\mathbf{E} \\
\end{array}$ & ROA & $\underset{I}{\text { ROA }}$ & $\underset{\text { II }}{\text { ROA }}$ & $\begin{array}{l}\mathbf{R} \\
\mathbf{O} \\
\mathbf{A}\end{array}$ & $\begin{array}{l}\mathbf{R} \\
\mathbf{O} \\
\mathbf{E}\end{array}$ \\
\hline & & & & & & & \multicolumn{2}{|c|}{ region } & & & & \multicolumn{2}{|c|}{$\begin{array}{c}\text { a, El } \\
\text { Salvador } \\
, \\
\text { Hondura } \\
\text { s, } \\
\text { Mexico, } \\
\text { Paragua } \\
\text { y) }\end{array}$} \\
\hline Research period & \multicolumn{2}{|c|}{ 2004-2011 } & \multicolumn{2}{|c|}{$\begin{array}{c}2005- \\
2010\end{array}$} & \multicolumn{2}{|c|}{$\begin{array}{c}2003- \\
2009\end{array}$} & \multicolumn{2}{|c|}{$\begin{array}{l}2002- \\
2009\end{array}$} & $\begin{array}{l}1984- \\
2010\end{array}$ & \multicolumn{2}{|c|}{ 2006-2013 } & \multicolumn{2}{|c|}{$\begin{array}{l}2005- \\
2013\end{array}$} \\
\hline
\end{tabular}

